\title{
Pluralisme Agama dan Modernitas Pembangunan: Rekonstruksi Pemikiran Pluralisme dalam Membentuk Etika Universal
}

\author{
Burhanudin Mukhamad Faturahman \\ Universitas Brawijaya \\ Corresponding e-mail : burhanmfatur@gmail.com
}

\begin{abstract}
Social conflict that occurred in Indonesia with a religious background is very concern. Religious pluralism should be the yardsticks religious tolerance in the midst of diversity, tolerant attitude of trust with fairness in order toward a civil society. In addition modernity allegedly subverts the social order because it creates an unfair economic system. The purpose of this writing to discuss religious pluralism with the value contained in it in terms of thinking Dawan Rahardjo, Nurcolish Madjid and John Hick with a contribution of modernity against the onset of social conflict. The research of religious pluralism in Indonesia namely according to Rahardjo addressed as a social integration as the Foundation behave because actual religions taught the values of public virtue while Madjid argued civil society is Home of democracy with an ethic of community as the quality of the life of democracy. Hick States pluralism as centering yourself towards the single reality of centering (of God) through different forms and ways. This diversity is vulnerable to conflict because of modernity triggered poverty, environmental destruction and communal violence. Therefore strengthening the education of multi religious and ethical global College absolutely implemented in an effort to create a civil society.
\end{abstract}

Keyword: civil society, ethics, modernity, pluralism.

Abstrak. Konflik sosial yang terjadi di Indonesia dengan latar belakang agama sangat memprihatinkan. Pluralisme agama seharusnya menjadi tolok ukur toleransi antar umat beragama di tengah keberagaman kepercayaan dengan sikap toleran, berkeadilan dalam rangka menuju civil society. Selain itu modernitas disinyalir merusak tatanan sosial karena menciptakan sistem ekonomi yang tidak adil. Tujuan penulisan ini untuk membahas pluralisme agama beserta nilai yang terkandung didalamnya ditinjau dari pemikiran Dawan Rahardjo, Nurcolish Madjid dan John Hick beserta kontribusi modernitas terhadap timbulnya konflik sosial. Hasil penelitian yaitu pluralisme agama di Indonesia menurut Rahardjo disikapi sebagai integrasi sosial sebagai dasar berperilaku karena sebenarnya agama-agama mengajarkan nilai-nilai kebajikan umum sedangkan Madjid berpandangan civil society adalah rumah dari demokrasi dengan etika masyarakat sebagai kualitas dari kehidupan demokrasi. Hick menyatakan pluralisme sebagai keterpusatan pada diri sendiri menuju keterpusatan pada sang Realitas tunggal (Tuhan) melalui berbagai bentuk dan cara. Keberagaman ini rentan konflik karena modernitas memicu terjadinya kemiskinan, rusaknya lingkungan dan kekerasan komunal. Oleh karena itu penguatan pendidikan multi agama dan etika global pada perguruan tinggi mutlak dilaksanakan sebagai upaya menciptakan civil society.

Kata kunci: civil society, etika, modernitas, pluralisme. 


\section{PENDAHULUAN}

Perdebatan mengenai fenomena pluralitas dalam kehidupan berbangsa dan bernegara selalu menarik untuk dikaji. Fatwa Majelis Ulama Indonesia (MUI) tentang keharaman pluralitas pada tahun 2005 yang menyamakan pluralitas dengan liberalisme dan sekularisme memberikan respon kritis di kalangan intelektual muslim terhadap fatwa tersebut. Terdapat banyak tulisan yang sangat kritis untuk pemaknaan pluralitas sempit tersebut diantaranya M. Dawam Rahardjo: Mengapa Semua Agama Itu Benar? (2006), Martin Lukito Sinaga: Agama Tanpa Sosiologi Agama, Meninjau Wacana Pluralisme di Indonesia (2006), Trisno S. Susanto: Membaca (kembali) Poliltik Pluralisme, Catatan untuk Martin Lukito Sinaga (2006). Kedua tulisan ini mengkritisi fatwa pluralisme oleh MUI yang miskin perspektif dan memantik kontroversi. Sedangkan tulisan Rahardjo, menurutnya dalam mengadapi keberagaman kita membutuhkan pluralisme. Konsekuensinya yaitu jika satu pihak menerima pluralitas sebagai realitas sedangkan pihak lain menolak pluralisme sebagai suatu paham.

Indonesia sarat dengan pluralitas dan pluralisme terutama yang terkait dengan agama sebagai takdir dan selalu berada dalam posisi problematis. Menurut salah satu teori sejarah, Islam datang ke bumi nusantara pada abad ke-7 M akan tetapi Islam tidak memasuki ruang hampa. Jauh sebelum datangnya Islam, masyarakat Nusantara telah terpola ke dalam berbagai agama dan kepercayaan. Agama-agama lainnya pun berdatangan. Dalam versi negara, pada saat ini ada enam agama yang diakui eksistensinya, yaitu: Islam, Kristen, Katolik, Hindu, Budha, dan Konghucu. Sisi problematis dari keragaman tersebut adalah adanya potensi konflik. Pertanyaan pentingnya mengapa agama dapat menimbulkan konflik?. Ini terdengar aneh karena ajaran agama apapun selalu menekankan pada kesamaan dan kesetaraan manusia. Ini merupakan visi perenial semua agama. Potensi konflik keragaman agama yang demikian ini berada di luar wilayah perenial agama, lebih banyak terjadi pada wilayah konstruksi sosial.

Mengapa wilayah ini rentan konflik? Konstruksi merupakan modus yang dikembangkan oleh seseorang dalam memahami doktrin agama. Agama memang meniscayakan pada suatu modus pemahaman agar kehendak Tuhan yang terdapat dalam doktrin agama bisa dipahami dan dilaksanakan oleh pengikutnya yang dimuat dalam AlQur'an, Injil, dan kitab-kitab lainnya. Dalam menjembatani aktualisasi nilai-nilai dalam kitab-kitab tersebut maka diperlukan pemahaman manusia. Jadi, tidak mungkin beragama tanpa didasari oleh konstruksi. Tetapi, hasil konstruksi manusia terhadap agama tidaklah tunggal (pluralitas internal) pada akhirnya tidak bisa dihindari.

Konstruksi tidak hanya menimbulkan masalah dalam lingkup internal agama saja misalnya antara Sunni dan Syiah dalam Islam. Konstruksi tersebut juga berpengaruh terhadap agama lain, katakanlah antara Hindu dan Islam, Islam dan Kristen, Budha dan Hindu dan seterusnya. Masing-masing (konstruksi) agama selalu ada keinginan membandingkan antara agama sendiri dengan agama lain yang kemudian berujung pada suatu klaim kebenaran (truth claim) terhadap keunggulan dalam hal otentisitas agamanya sendiri. Sebaliknya, jika pemahaman pluralitas tersebut dimaknai sebagai relaitas dan juga paham maka sikap toleransi beragama sangat mungkin diciptakan. Menurut Rosyid (2014) keselarasan beda agama dan aliran di Kudus merupakan cerminan pluralitas antara Nahdliyin, 
Kristiani, Buddhis, dan Ahmadi. Kerukunan terwujud karena adanya kesadaran akan kesamaan aspek budaya. Selain itu, mayoritas ekonomi masyarakat pada skala sedang (tidak miskin) sehingga tidak mudah tersulut konflik, tidak adanya loko pemicu konflik. Terakhir, adanya ikatan kekeluargaan dan keakraban dalam kehidupan sosial antar dan intern-pemeluk agama dan aliran.

Hidup dalam nuansa pluralitas merambah bidang bidang lainnya meliputi bidang ekonomi, sosial maupun bidang lain yang berpotensi. Kasus penistaan agama yang dilakukan Ahok saat berbicara di Kepulauan Seribu tanggal 27 September 2016 yang mengutip ayat Alquran surat Al-Maidah ayat 51 memberikan sinyalemen bahwa hukum juga harus bertindak secara tegas dan responsif. Menurut Kombes Heri, Polisi sudah menetapkan Ahok menjadi Tersangka dalam hal Penistaan Agama tersebut dan melanggar pasal 156 KUHP dan atau Pasal 156a KUHP dan UU ITE tetapi jaksa tidak memakai UU ITE dalam Dakwaannya. Lebih hanya kepada kedua pasal tersebut dalam Surat Edaran Kapolri tentang Ujaran Kebencian SE/06/X/2015 (Akbar, 2017).

Memudarnya sikap intoleransi merupakan dampak dari sikap fanatik dibingkai dalam klaim kebenaran absolut. Dalam klaim kebenaran sebenarnya terjadi pembatasan (teritorialisasi) secara rigit antara pemahaman yang benar dan yang salah. Sebagaimana yang terjadi dalam pembatasan yang bersifat geografis, pembatasan dalam wilayah agama juga ditandai dengan adanya sikap protektif dan konservatif agar wilayah (pemahaman) yang dianggap salah, tidak merusak wilayah yang benar. Oleh karena itu, terdapat persyaratan yang ketat untuk memasuki dan diakui sebagai bagian pemahaman yang benar selanjutnya menurut Esack (1997) membentuk sikap konservatisme. Jika terjadi terhadap kaum Muslim, konservatisme ditandai semakin sempitnya basis teologis dalam mendefinisikan iman, Islam, dan memperluas basis bagi kufur sehingga semakin sedikit yang dianggap beriman dan makin banyak yang digolongkan kafir. Lebih ekstrim membuat jarak dengan kelompok atau agama lain semakin lebar.

Semakin renggangnya jarak sosial sangat mengancam keutuhan kehidupan (disintegrasi) berbangsa dan bernegara dalam rangka mencapai mencapai tujuantujuan politik, sosial, dan ekonomi mencakup peningkatan kesejahteraan hidup, keadilan sosial dan rasa aman bagi setiap anggota masyarakat (human security). Untuk mencapai tujuan tersebut maka usaha modernisasi, pembangunan, demokratisasi dan pembaharuan ekonomi. Pertanyaan penting yang harus dijawab apakah model pembangunan yang selama ini dilakukan oleh pemerintah Indonesia sudah berkontribusi dalam meningkatkan kesejahteraan serta menciptakan rasa aman masyarakat ?. Sementara itu di beberapa daerah yang dilanda konflik seperti Aceh dan Papua rakyat kecil semakin kehilangan rasa aman karena menjadi korban akibat konflik negara dengan kelompok separatis. Sumandoyo (2015), Konflik di Aceh dilatar belakangi masalah kekuasaan dimana terdapat perbedaan kepentingan politik siapa menguasai siapa, kepentingan ekonomi sehingga mengakibatkan konflik. Meskipun secara formal sudah tuntas tetapi pembangunan dan proses politik di Aceh tidak menguntungkan bagi rakyat banyak. (Asad Said Ali, 2015 merdeka.com).

Sedangkan konflik di Papua terjadi karena pendekatan ekonomi dan kesejahteraan termasuk pendekatan 
agama tidak dilakukan. Papua terdapat banyak gereja katolik, protestan notabene nasionalis. Ada 2 (dua) syafaat yang dianut, sebagian (gereja) yang baru disetir dari luar negeri dan perlu diingatkan bagaimana pentingnya berbangsa. Gereja pun harus menumbuhkan jiwa nasionalisme. Boleh menerima bantuan dari luar negeri akan tetapi harusa ada filter untuk kepentingan bangsa dan negara (Asad Said Ali, 2015 merdeka.com). Aceh dan Papua yang kaya akan sumberdaya alam ternyata menjadi kantong-kantong kemiskinan yang kemudian melahirkan tindak kekerasan sebagai senjata untuk melawan ketidakadilan sosial. Hingga kini kasus seperti terorisme masih marak terjadi. Serangkaian ledakan yang terjadi di tiga area Gereja di Surabaya bulan Mei 2018, yakni, Gereja Katolik Santa Maria Tak Bercela, GKI dan Gereja Pantekosta disusul dengan ledakan bom di Mapolrestabes Surabaya hari esoknya membuat ancaman disintegrasi bangsa semakin nyata.

Pluralisme di Indonesia bukan saja dimaknai sebagai keberagaman entitas antar agama, budaya, etnis semata namun makna tersebut dipahami sebagai perwujudan keshalehan sosial. Di sisi lain, pluralitas itu sendiri berpotensi menjadi bencana sosial ketika ketimpangan pembangunan masih terjadi. Ketimpangan yang tinggi juga menyulut aksi radikalisme dan terorisme. Ketimpangan tinggi terdapat di 8 kota dengan gini rationya di atas tingkat nasional. Gini ratio tertinggi berada di kota Yogyakarta sebesar 0,425, Gorontalo 0,410, Jawa Timur 0,402, Jawa Barat 0,402, Papua Barat 0,401, Sulawesi Selatan 0,400, Papua 0,399, dan Jakarta sebesar 0,397 (kumparan.com, 2017). Berangkat dari permasalahan yang telah diuraikan bahwa modernisasi merupakan salah satu upaya pembanguan menuju kesejahteraan dan keamanan sosial mengandung resiko cukup tinggi yang harus diantisipasi. Tujuan daripada penulisan ini yaitu memahami pluralitas beragama sebagai pemahaman dan relevansi modernisasi pembangunan dalam menjaga kemanan sosial.

\section{METODE PENELITIAN}

Peneliti menggunakan penelitian kepustakaan, yakni mengkaji sejumlah bahan pustaka yang bertujuan untuk mendeskripsikan dan atau merekonstruksi fenomena-fenomena sosial tertentu secara obyektif dan akurat. Bahan-bahan kepustakaan yang dikaji adalah pemikiran Nurcholish Madjid, M. Dawam Rahardjo dan John Hick. Dua tokoh pertama memiliki perhatian yang besar terhadap perkembangan wacana pluralisme di Indonesia. Sedangkan John Hick adalah salah satu pemikir modern yang berbasis filsafat serta mengedepankan pentingnya perdamaian dalam kritisismenya terhadap teologi agama-agama. Permasalahan modernitas pembangunan juga turut dikaji karena modernisasi turut memberikan kontribusi konflik di negara sedang berkembang khususnya Indonesia.

\section{HASIL DAN PEMBAHASAN}

\section{A. HASIL}

\section{a. Wacana Rekonstruktif Pluralisme}

Persoalan kemajemukan ini penting untuk diperhatikan karena dua hal yakni pertama, fakta kemajemukan agama di Indonesia beserta permasalahannya yang begitu kompleks. Kedua, terkait masa depan hubungan antar umat beragama di Indonesia. Oleh karena itu pendekatan dalam ilmu-ilmu sosial dan keagamaan yang saling menguatkan. Kajian pluralitas agama bukanlah hal baru di Indonesia karena pada tahun 1961 di IAIN Yogyakarta membuka jurusan Perbandingan Agama di bawah pembinaan A. Mukti Ali. Jika 
dibandingkan dengan kajian periode sebelumnya, penekanan kajian kemajemukan pada tahun 90- an lebih pada upaya untuk mencari titik temu (modus vivendi) antara agama yang satu dengan agama lain melalui pendekatan dialogis. Pendekatan ini mendapat porsi yang besar pada saat itu. Pada saat yang sama, tahun 90-an kejadian beruntun konflik memusatkan pada aspek perbedaan agama. Dan sampai saat ini konflik tersebut terus berlanjut. Fakta inilah, kajian terhadap kemajemukan agama di Indonesia perlu terus dikembangkan.

Menciptakan ruang dialog antar agama bukan hal yang mudah. Kendala itu justru disebabkan cara berpikir agama yang kurang kritis. Akar konflik teologis menurut D'adamo dalam Arifin (2009) adalah berawal dari sebuah standar tentang agamanya sendiri -kitab sucinyamerupakan sumber kebenaran yang sepenuhnya diyakini. Pandangan D'adamo tentang standar ganda: 1) Bersifat konsisten dan berisi berbagai kebenaran tanpa kesalahan sama sekali. 2) Bersifat lengkap dan final. Oleh karenanya kebenaran dari agama lain tidak diperlukan. 3) Menyakini agama sendiri sebagai satu-satunya jalan keselamatan, pencerahan atau pembebasan. 4) Menyakini bahwa seluruh kebenaran itu diyakini berasal dari Tuhan tanpa konsttruksi manusia.

Sikap semacam ini masih sarat dengan teologi formal tradisional. Teologi formal tradisional (Said,2005) kurang memberikan sentuhan yang berarti untuk mengikuti perkembangan ilmu-ilmu sosial dan historisitas keagamaan yang tidak bisa dilepaskan dari tradisi sejalan dengan ruang dan waktu yang membingkainya. Perspektif berpikirnya terus berputarputar di wilayahnya sendiri dan kurang menyentuh teologi keagamaan lainnya.
Teologi yang terbangun kurang memiliki ruang bagi orang lain untuk dapat menanggapi teologi yang dianutnya. Sehingga teologi keagamaan tidak punya komitmen terhadap nilai-nilai kemanusiaan universal sebagaimana teologi yang diusung teror serta konflik horizontal dengan faktor keagamaan sebagai pemicunya.

\section{b. Pluralisme dalam masyarakat madani: Pemikiran M. Dawam Rahardjo}

Dawam Rahardjo merupakan tokoh intelektual yang memiliki perhatian besar terhadap wacana pluralisme dengan konsep civil society (masyarakat madani) yang juga marak di Indonesia. Masyarakat madani menurut pemikiran Rahardjo memiliki dua esensi penting yaitu nilainilai kebajikan umum dan integrasi sosial. Rahardjo dalam Arifin (2009) menjelaskan masyarakat madani adalah masyarakat yang mengacu pada nilai kebajikan umum yang disebut al-khair. Masyarakat ini harus dipertahankan dengan membentuk persekutuan, perkumpulan, perhimpunan, dan sebagainya yang memiliki visi dan pedoman bertindak. Dasar utama dari masyarakat madani adalah integrasi sosial yang didasarkan pada pedoman hidup, menghidarkan diri dari konflik serta permusuhan yang berakibat perpecahan persaudaraan. Atas dasar ini masyarakat diperintahkan untuk membentuk perhimpunan dengan cita-cita kebajikan umum karena (Q.S. al-Imran: 104) menjelaskan "dan hendaklah ada di antara kamu segolongan umat yang menyeru kepada kebajikan umum (alkhair), menegakkan yang ma'ruf dan mencegah yang mungkar. Mereka itu adalah orang-orang yang mencapai kebahagiaan (al-falah).

Nilai kebajikan dan integrasi sosial inilah menurut Rahardjo merupakan inti dari piagam madinah pada zaman Nabi SAW. Prinsip-prinsip utama dalam 
piagam madinah yakni pertama pengakuan bahwa mereka bagian dari integrasi sosial yang disebut al-ummah. Kedua, mereka tunduk pada nilai-nilai luhur yang disebut al-khair (kebajikan) digunakan untuk menegakkan nilai keadilan, perdamaian, kesamaan dan kebebasan Ketiga, mekanisme tersebut untuk menentukan tindakan yang baik dan yang buruk dalam artian sebagai pemimpin mampu merubah keadaan mejadi lebih baik (Faturahman, 2018b). Kebajikan dapat diwujudkan melalui perlindungan terhadap negara, terhadap jiwa dan harta, kebebasan beragama, keamanan, kepastian hukum dan musyawarah. Adapu hal yang perlu dicegah yaitu kekacauan, kezaliman, pengrusakan, pertikaian dan agresi dari luar (Arifin, 2009:86).

Dari pandagan ini Rahardjo menggunakan preferensi keagamaan untuk mengkonstruksi masyarakat madani. Sikap ini menunjukkna sikap yang positif-konstruktif terhadap peran agama. Agama di Indonesia dapat dijadikan faktor integratif masyarakat madani dalam menghindari konflik sosial. Berikut kutipan Arifin (2009:86) agama bisa merupakan konflik maupun harmonisasi menurut Rahardjo:

“...teori modern 'menghargai' dan mempertimbangkan agama sebagai faktor integratif. Karena itu, maka proses modernisasi dan perkembangan ekonomi yang menggoyahkan sendi-sendi agama ditangapi dengan sikap 'prihatin' oleh berbagai ahli ilmu sosial. Itulah agaknya yang memberi penjelasan, mengapa berbagai ilmu-ilmu sosial 'mempertimbangkan' kembali agama dan tujuan mengambil pelajaran mengapa dalam masyarakat primitif berfungsi positif sebagai faktor integratif. Pendekatan fungsional terhadap agama menghasilkan dua gagasan. Pertama, menciptakan substitusi agama dengan membentuk instituai-institusi yang mengandung solidaritas or ganis, misalnya institusi negara. Atau menempatkan posisi agama dan pada fungsinya yang dipandang tepat sebagai pemeliharaan pola-pola latin, dengan resiko, agama bisa merupakan kekuatan oposisi yang mengontrol perilaku".

Dalam kehidupan masyarakat modern saat ini, terdapat lembaga-lembaga substitusi agama berdasarkan logika solidaritas organis. Negara merupakan jelmaan dalam mewujudkan solidaritas tersebut. Negara yang terbentuk ini turut memarginalisasi fungsi agama. Namun jika agama dalam negara benar-benar memiliki fondasi kuat maka agama tetap bertahan sebagai kekuatan latin dan merupakan sumber perubahan sosial. Untuk menjalankan fungsinya secara luas, agama menurut Rahardjo diperankan sebagai agama profetis. Agama profetis artinya agama yang tidak murni spiritual melainkan juga mengedepankan sosial dan politik sebagaimana peran agama zaman kenabian. Agama dalam negara memiliki dua bentuk: 1) bentuk kependetaan dimana agama memiliki peran lebih sebagai penyangga status quo dan memelihara integrasi melalui penyelenggaraan ritus-ritus. 2) agama bisa berperan sebagai kekuatan pembebas (agama profetis).

Agama dapat berperan secara profetis jika agama dirumuskan ke dalam suatu teologi yang responsif terhadap persoalan-persoalan konkret di masyarakat. Agama profetis mengarahkan kembali akar pemikiran yang paling fundamental (kebenaran, keadilan dan keindahan serta menyadari sisi kemanusiaannya). Acuan seperti ini menciptakan sikap kritis terhadap lingkungan dan alam fikiran yang mapan, termasuk alam pikiran keagamaan sendiri. Kecenderungan seperti ini akan melahirkan teologi kontekstual dan 
mengacu

kepada

pembaharuan masyarakat. Dengan sendirinya, aliran ini memiliki resiko konflik perpecahan demi perubahan. Pada akhirnya teologi bercorak profetis memberikan tantangan pada agama kependetaan dalam menjaga status quo. Diakui peran agama profetis mengadung banyak resiko namun masih memiliki kemungkinan untuk berkembang asalkan tidak menjurus pada radikalisme "fundamentalisme" atau radikalisme “teologi pembebasan". Selanjutnya peran profetik membuka cakrawala melakukan dialog antar-iman dan berkehendak untuk melakukan komunikasi, karena telah mengambil sikap kritis terhadap apa yang mereka yakini selama ini. Peran diaolgis inilah membuka ruang selanjutnya bagi perumusan platform bersama yang lebih luas.

\section{c. Pluralisme dan Etika Sosial dalam Masyarakat Madani: Nur Cholish Madjid}

Istilah masyarakat madani sebagaimana yang dikemukakan oleh kelompok Nurcholish yang berarti masyarakat yang beradab, berakhlak mutlak, dan berbudi pekerti luhur. Dalam islam masyarakat madani merujuk kepada seluruh masyarakat baik itu individu, keluarga, maupun negara, yang semuanya memiliki sifat dan budaya teras (berperadaban) untuk mewujudkan suatu masyarakat yang menegakkan nilai-nilai kebaikan (ma'rūf) demi terbentuknya masyarakat yang beradab (tamaddūn). Model masyarakat ideal dalam sejarah Islam ialah masyarakat dan negara Madinah. jika dalam masyarakat Barat, civil society akhirnya adalah demokrasi yang lahir setelah proses sekularisasi. Masyarakat Islam, civil society (masyarakat madani) dibentuk dengan landasan, motivasi, dan etos keagamaan. Dari sini, Madjid memberikan porsi lebih pada agama atau kriteria paling utama mayarakat madani (Madjid,2000).

Terdapat tiga tema besar rumusan masyarakat madani menurut Madjid. Pertama: demokrasi, kedua: masyarakat madani (civil society), dan ketiga: civility. Beliau berpandangan bahwa masyarakat madani adalah rumah bagi demokrasi dimana berbagai macam perserikatan, klub, gilda, sindikat, federasi, persatuan, partai dan kelompok bergabung untuk menjadi perisai antara negara dan warga negara Sedangkan civility merupakan kualitas etik masyarakat madani, seperti keterbukaan, toleransi, dan kebebasan yang betanggung jawab. Madjid menyatakan bahwa kualitas masyarakat madani sangat ditentukan oleh sejauh mana civility tersebut dimiliki warganya. Civility mengandung makna toleransi, yang mempunyai arti kesediaan pribadipribadi untuk menerima berbagai macam pandangan politik dan tingkah laku sosial, juga bersedia untuk menerima pandangan bahwa tidak selalu ada jawaban yang benar atas suatu masalah (Yasmadi,2005). Cirinya yakni:

a. Egalitarianisme

Madjid menyatakan faktor yang sangat fundamental dan dinamis dari etika sosial dalam ialah egalitarianisme. Perbedaan keimanan, warna kulit, ras, maupun status sosial atau ekonominya dianggap tidak ada. Semua dianggap sebagai partisipan yang sama dalam komunitas. Selanjutnya egalitarianisme Islam menyangkut rasa keadilan, keberadaan, kerakyatan dan persamaan, prinsip musyawarah (demokrasi partisipatif), hikmat (wisdom), dan rasa perwakilan (representativeness).

b. Keterbukaan

Keterbukaan yaitu kesediaan menerima dan mengambil nilai-nilai (duniawi) yang mengandung kebenaran. Al-Quran memerintahkan bagi kaum 
Muslim untuk mendengarkan pikiranpikiran dan mengikuti mana yang paling baik. Menurut Madjid keadaan umat Islam sekarang ini lebih cenderung dan bersifat tertutup, berdada sempit dan sesak seperti orang yang terbang ke langit, dan itu merupakan salah satu tanda kesesatan. Sikap terbuka akan menumbuhkan kesadaran sesama manusia dan sesama makhluk untuk saling menghargai dan menghormati pada diri seseorang, berbentuk hubungan sosial yang saling mengingatkan tentang apa yang benar, tanpa memaksakan kehendak pribadi wujud dari ketaqwaan.

c. Penegakan hukum dan keadilan

Keadilan dalam Al-Quran menurut Madjid dinyatakan dengan istilah'adl dan qisth. Pengertian adil juga terkait dengan sikap seimbang dan menengahi (fair dealing), dalam semangat moderniasasi dan toleransi, yang dinyatakan dengan istilah wasath (pertengahan). Sikap seimbang memberikan kesaksian dengan adil, karena dilakukan dengan pikiran tenang dan bebas dari sikap berlebihan, tidak bisa mementingkan diri sendiri, melainkan dengan pengetahuan yang tepat mengenai suatu persoalan dan mampu menawarkan keadilan (lihat Q.S. AnNisa: 135).

d. Toleransi dan kemajemukan

Satu asas masyarakat madani (civil society) yang dicita-citakan oleh semua orang adalah toleransi. Indonesia, Sebagian besar masyarakatnya beragama Islam, dan itu bisa disebut sebagai dukungan terhadap paham toleransi karena Islam telah melaksanakan pengalaman toleransi pada kehidupan nyata. Sebagai contoh bukti bahwa Islam menjadi panutan mayoritas, agamaagama lain tidak mengalami kesulitan berarti. Tapi jika kaum Muslim menjadi minoritas, mereka selalu mengalami kesulitan yang tidak kecil, kecuali di negara-negara demokratis barat karena memperoleh kebebasan beragama yang menjadi hak mereka. Pola hidup manusia menganut hukum Sunnatullāh tentang pluralitas, antara lain karena Allah SWT menetapkan jalan dan pedoman hidup yang berbeda untuk berbagai golongan manusia.

\section{e. Musyawarah}

Musyawarah selalu menjadi tema penting dalam setiap pembicaraan tentang politik demokrasi (Faturahman, 2018a), dan tidak dapat dipisahkan dari konsep politik Islam. Madjid, musyawarah secara kebahasaan berarti saling memberi isyarat tentang apa yang baik dan apa yang benar sesuai ajaran agama untuk selalu berbuat kebenaran. Kebenaran sebagai syarat ketiga keselamatan manusia, setelah syaratsyarat iman dan amal shaleh. Musyawarah sebagai proses politik yaitu yang disebut dengan istilah partisipasi, kebebasan, dan persamaan. musyawarah mustahil dijalankan tanpa kehadiran dari ketiga elemen tersebut. Tidak mungkin mengadakan musyawarah tanpa adanya kehadiran, baik secara langsung maupun secara tidak langsung. Musyawarah juga tidak mungkin diwujudkan tanpa adanya kebebasan untuk menyatakan pendapat atau freedom of expression. Dan dalam pengambilan keputusan dalam musyawarah dilandasi oleh kebebasan dan haruslah didasari oleh semangat persamaan atau equality (Hidayat,1995).

\section{d. Nalar Pluralisme Agama Hick}

Menurut Hick tantangan keagamaan sekarang ini adalah pluralisme. Bukan berarti pluralisme merupakan tantangan satu-satunya, tetapi jika pluralime tidak diperhatikan dengan sungguh-sungguh agama akan kehilangan kebenaran tentang dunia dan masyarakat tempat mereka hidup. Jaringan komunikasi menembus 
batas-batas kelompok antar umat agama yang awalnya mengisolasi kelompok tersebut. Hipotesa pluralisme Hick berangkat dari tiga alasan. Pertama, kebanyakan orang secara intuitif memiliki satu tujuan yang sama. Kedua, pluralitas diwacanakan secara jelas dan persuasif. Ketiga, hipotesanya dapat merespon terhadap kegelisahan teologis keagamaan yang plural.

Hick dalam "pluralistic hypothesis" menyatakan semua agama-agama secara kultural merupakan sebagai respon terhadap realitas puncak yang sama (Hick,1995). Berikut empat faktor kritis mengenai fenomena keagamaan: 1) Fakta setiap orang pada dasarnya adalah religious, 2) Hasil observasi terdapat perbedaan substansial yang tampak secara lahiriah dalam kepercayaan keberagamaan. 3) Asumsi bahwa kepercayaan keagamaan bukanlah ilusi. 4) Kesadaran bahwa hampir semua tradisi keagamaan secara positif mampu merubah pola hidup penganutnya.

Pembahasan bahwa kepercayaan bukanlah ilusi dapat dilihat dari pendekatan naturalisme dan absolutisme. Menurut naturalisme semua masalah keagamaan yang berhubungan dengan relitas puncak adalah palsu, Hick menolak pandangan ini. Lorens (1996:688) Naturalisme biasanya mengarah kepada pandangan filosofis yang memberikan suatu peranan menentukan atau bahkan suatu peranan eksklusif kepada alam dengan menekankan oposisinya terhadap roh atau tata adikrodat. Pendekatan absolutisme menyebut bahwa hanya ada satu sistem kepercayaan keagamaan yang secara literal adalah benar sementara sistem kepercayaan yang lain adalah salah. Pendekatan ini Hick juga tidak sependapat. Hick menyadari absolutisme bisa diterima pada satu tradisi tertentu, namun pada tingkat realitas keberagamaan yang kompleks tentu tidak akan menemukan relefansinya.

Problematika yang demikian Hick memberikan alternatif pemikiran, intinya keagamaan dapat ditempuh melalui berbagai pengalaman hakikat tersebut berada pada realitas paling utama (ultimate reality) bersifat transedental dari berbagai bentuk dan macamnya. Hick menerapkan konsep distingsi Imanuel Kant dalam memahami perbedaan fenomena keagamaan antara the Real sebagai sesuatu yang eksis dan the Real sebagai hasil pemahaman dari pengalaman individu dalam tradisi tertentu. Oleh karena itu, terjadinya perbedaan persepsi seperti itu akibat tidak adanya akses secara langsung kepada the Real sehingga melahirkan konflik konsepsi terhadap the Real. Semua persepsi terhadap the Real selalu melalui mediator yaitu tradisi keagamaan yang unik yang dalam istilah Hick disebut sebagai "konsep lensa " (conceptional lens).

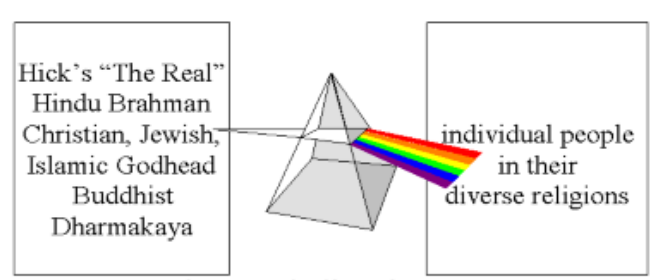

Gambar 1. Analogi Prisma-Lensa Pluralisme John Hick (Said,2015)

Ringkasan hipotesa pluralitas Hick dapat disimpulkan sebagai berikut: 1. Ada satu relitas ketuhanan, the Real, di mana sumber akhirnya adalah pengalaman keagamaan, 2. Tidak ada tradisi keagamaan yang memiliki persepsi secara langsung terhadap the Real, 3.Masingmasing tradisi keagamaan memiliki jalan yang benar menuju kepada the Real, 4 . The Real bersifat transenden dari berbagai pemahaman. Hick menilai pluralisme sebagai pandangan yang menyatakan bahwa perubahan hidup manusia dari 
keterpusatan pada diri sendiri menuju keterpusatan pada sang Realitas tunggal (Tuhan) terjadi pada semua agama melalui berbagai bentuk dan cara (Hick,1985).

\section{e. Modernisasi dan Pembangunan}

Menarik dibahas bahwa disintegrasi bangsa bermula dari konsep pembangunan yang kurang tepat. Dalam pembahasan ini penulis melihat modernisasi sebagai langkah awal munculnya berbagai masalah pembangunan. Untuk itu perlu dibedakan antara modernisasi dan pembangunan. Modernisasi menurut Dankwart A. Rustow identik dengan industrialisasi dimana kerja sama antar manusia menciptakan kontrol atas alam. Cyril E. Black mengungkapkan modernisasi adalah proses transformasi masyarakat akibat dari revolusi penggunaan ilmu dan teknologi. Agpalo (1992) menyebut ada dua faktor definisi modernisasi yaitu waktu dan pengetahuan. Faktor waktu berarti mengaitkan modernisasi jaman sekarang jauh lebih baik dari yang ada sebelumnya karena dianggap ketinggalan jaman. Sehingga yang dianggap baru pada ilmu dan teknologi harus diadopsi dalam ekonomi dan politik. Selanjutnya faktor pengetahuan dan teknologi berarti menujuk pada akumulasi iptek pada negara modern lebih banyak ketimbang negara yang belum modern.

Perbebedaan antara modernisasi dan pembangunan dapat dilihat pada proses industrialisasi. Industrialisasi merupakan pembangunan industri (perwujudan teknologi dan manajemen modern menitikberatkan efisiensi produksi) yang belum bisa disebut pembangunan karena hanya menguntungkan pemiliki modal sembari mengorbankan mayoritas rakyat untuk kepentingan industri. Belum cukup itu, kerusakan lingkungan dan menurunnya kualitas kehidupan turut disertakan. Pembangunan rumah mewah, pusat perbelanjaan, hotel dan lain-lain diklaim sebagai modernisasi kota tapi belum berdampak positif bagi seluruh warga kota tersebut. Modernisasi juga dianggap sebagai gejala developementalisme. Gejala developmentalisme (Jemadu,2003) yakni pertama, pencapaian angka pertumbuhan ekonomi mengabaikan angka pemerataan (kesejangan bertambah) dan keadilan sosial. Kedua, pembangunan mengorbankan pelestarian lingkungan hidup (eksploitasi sumberdaya alam). Ketiga, hak sipil dan hak politik rakyat dikorbankan demi stabilitas politik negara. Keempat, berkembangnya mental suka menghutang (utang luar negeri) sebagai dana pembangunan infrastruktur. Kelima, korupsi semakin menjadi karena kolusi antara pengusaha dan penguasa untuk pertumbuhan ekonomi. Keenam, hilangnya kreatifitas dan inisiatif bangsa untuk pembangunan yang bersifat mandiri. Ketujuh, konflik sosial cenderung menggunakan pendekatan keamanan bagi upaya yang menghalangi pembangunan nasional dan mengganggu stabilitas nasional.

Modernisasi yang demikian ini oleh Agpalo (1992) harus diimbangi dengan proses civilization. Proses ini berupa transformasi situasi barbarisme (dominasi kaya atas miskin, kota atas desa, modern atas tradisional) menjadi situasi pembangunan politik. Adapun indikator pembangunan politik ini yaitu tegaknya hukum, civility atau rasa kebersamaan membela kepentingan umum dan keadilan sosial. Yang masih dicapai oleh Indonesia saat ini masih pada tahap modernisasi politik menjurus pada penciptaan lembaga-lembaga politik modern (partai politik) dan pemilihan umum. Ironisnya tujuan tersebut hanya untuk kepentingan kelompoknya kemudian menciptakan elitisme politik. Sebaliknya pembangunan politik dilakukan untuk meningkatkan indikator demokrasi: kontrol dari 
masyarakat pada setiap kebijakan publik untuk pembangunan (Faturahman, 2017) dan kesetaraan tanpa membedakan suku, agama, ras, status sosial dan ekonomi. Keadilan sosial hanya terwujud apabila seluruh warga masyarakat memiliki akses yang sama terhadap pemenuhan kebutuhan dasar hidup layak.

Korten (1990) menyatakan model pembangunan ekonomi berpusat pada pertumbuhan ekonomi bukan solusi yang tepat karena menambah angka kesenjangan si kaya dan si miskin. Lebih lanjut tiga unsur pokok dalam krisis global: kemiskinan, kerusakan lingkungan dan kekerasan komunal. Senada dengan kritikan Rahardjo (2012) bahwa modernisasi pembangunan lebih menekankan eksploitasi alam ketimbang membangun manusia mandiri. Modernisasi tersebut membuang tradisi pengetahuan dan kearifan lokal yang menjadi simbol peradaban Indonesia dan lebih mengancam kelestarian lingkungan dan merusak ekosistem. Pada gilirannya, modernisasi pembangunan berdampak pada marginalisasi usaha ekonomi. Berikut disajikan

Tabel 1. Konflik di Indonesia 2013 s.d 2015

\begin{tabular}{|c|c|c|}
\hline Tahun 2013 & Tahun 2014 & Tahun 2015 \\
\hline \multicolumn{3}{|c|}{ Berdasarkan sumber konflik UU No.7/2012 } \\
\hline $\begin{array}{l}\text { poleksosbud } 71 \text { kasus } \\
\text { Perseteruan SARA } 8 \text { kasus } \\
\text { Sengketa SDA/Lahan } 13 \text { kasus }\end{array}$ & $\begin{array}{l}\text { poleksosbud } 68 \text { kasus } \\
\text { perseteruan SARA } 1 \text { kasus } \\
\text { Sengketa SDA/Lahan } 14 \text { kasus }\end{array}$ & $\begin{array}{l}\text { poleksosbud } 20 \text { kasus } \\
\text { perseteruan SARA nol } \\
\text { sengketa } \quad \text { SDA/Lahan } \\
\text { berjumlah } 6 \text { kasus }\end{array}$ \\
\hline Tahun 2013 & Tahun 2014 & Tahun 2015 \\
\hline \multicolumn{3}{|c|}{ Berdasarkan isu/pola konflik } \\
\hline $\begin{array}{l}\text { bentrok antar warga } 37 \text { kasus } \\
\text { Isu keamanan } 16 \text { kasus } \\
\text { Isu SARA } 9 \text { kasus } \\
\text { konflik kesenjangan sosial } 2 \\
\text { kasus } \\
\text { konflik institusi pendidikan } 2 \\
\text { kasus } \\
\text { konflik ORMAS } 6 \text { kasus } \\
\text { sengketa lahan } 11 \text { kasus } \\
\text { ekses politik } 9 \text { kasus }\end{array}$ & $\begin{array}{l}\text { bentrok antar warga } 40 \text { kasus } \\
\text { Isu keamanan } 20 \text { kasus } \\
\text { Isu SARA } 1 \text { kasus } \\
\text { konflik ORMAS } 3 \text { kasus } \\
\text { sengketa lahan } 14 \text { kasus } \\
\text { ekses politik } 4 \text { kasus }\end{array}$ & $\begin{array}{l}\text { bentrok antar warga } 8 \text { kasus } \\
\text { Isu keamanan } 9 \text { kasus } \\
\text { Isu SARA } 9 \text { kasus } \\
\text { konflik ORMAS } 1 \text { kasus } \\
\text { sengketa lahan } 6 \text { kasus } \\
\text { ekses politik } 2 \text { kasus }\end{array}$ \\
\hline
\end{tabular}

Sumber : Baderi (2017)

Penambahan jumlah konflik horizontal masih memungkinkan mengingat pada tahun 2016 hingga 2018 ini masih marak terjadi konflik horizontal. Korten (1990) menegaskan semakin mengejar pertumbuhan ekonomi maka semakin terancam pula integrasi sosial dalam masyarakat dan tidak tercipta lagi komunitas kemanusiaan. Sebagai contoh, keterpurukan tersebut dapat dilihat dalam perhitungan pertumbuhan ekonomi yang memasukkan biaya pengobatan kanker akibat polusi zat kimia masuh dalam angka GNP. Jika memang pertumbuhan ekonomi merupakan solusi, seharusnya kemiskinan tidak meluas, kerusakan lingkungan semakin parah dan disintegrasi sosial.

Untuk itu sejumlah alternatif ditawarkan dalam mengatasi krisis pembangunan ini. Rao (2003) menyarankan pertama, pengurangan atau penghapusan utang luar negeri sangat urgent untuk dilakukan. Kemampuan 
finansial Indonesia sebagian besar digunakan untuk membayar cicilan hutang daripada untuk menutup defisit APBN. Tuntutan ini cukup adil karena sebagian dari utang luar negeri dikorupsi oleh pejabat. Kedua, melalui public investment dalam bidang pertanian dan sektor informal karena dua sektor ini adalah konsentrasi penduduk miskin. Selain itu, investasi di bidang usaha kecil dan menengah juga perlu mendapat prioritas. Sumber dana utama untuk keperluan investasi publik ini adalah optimalisasi pemungutan pajak yang selama ini masih belum optimal. Ketiga, Indonesia perlu memfasilitasi industriindustri yang bersifat strategis dan berpeluang untuk kepentingan ekspor sehingga mampu bersaing di pasar global.

\section{f. Membumikan Universalitas Agama dan Etika Melalui Pendidikan Tinggi}

Cerminan pendidikan agama pada sekolah-sekolah di Indonesia mulai dari sekolah dasar hingga tingkat perguruan tinggi dapat dikatakan monoteologi. Sangatlah maklum apabila lembaga atau yayasan tertentu yang bernaung pada suatu agama maka pendidikan agama yang diajarkan didominasi oleh ajaran agama yang dianut oleh lembaga tersebut. Dalam perkembangaannya agama menjadi sebuah kontestasi ajaran agama selain sebagai sosialisasi nilai-nilai. Kontestasi pertama berlangsung antara intern agama dan kontestasi kedua berlangsung antaragama. Kecenderungan agama sebagai keyakinan sangat dianjurkan dan diwajibkan. Keyakinan ini dapat dijadikan instrumen politik (regulasi) untuk memberikan sanksi jika tidak mematuhinya. Namun, disisi lain pengetahuan dan keberadaan agama lain diabaikan, agama lain dianggap buruk bahkan jarang mendapat tempat untuk diskusi dimana timbul klaim kebenaran terhadap agama sendiri semakin menguat.
Secara substansi ajaran agama memang mengandung unsur toleransi akan tetapi porsinya sangat kecil. Pengajarannya yang dangkal menekankan pada ritual, hafalan, istilah, doktrin dan konsep teologi saja. Hal semacam ini membuat pelajaran toleransi menjadi hilang maknanya lanjut pada aspek agama seperti hilang ditelan bumi. Sudah sangat umum jika agama Islam diajar oleh guru/dosen beragama Islam, agama Kristen/Katolik diajar oleh guru/dosen beragama yang beragama Kristen/Katolik, agama Hindu/Budha diampu oleh pengajar yang linier di agama tersebut. Dengan begitu agamaagama menjadi terkotak-kotak. Dari sinilah pengetahuan mengenal dan memahami agama lainnya menjadi penting. Perlu ditekankan terlebih dahulu bahwa mengenal bukan berarti percaya dan memahami bukan berarti menerima.

Terdapat ketakutan jika mengenal dan memahami agama lain maka dikhawatirkan akan berpindah agama. Tujuan mengenal dan agama lain tidak lain adalah mengurangi prasangka buruk agama lain dan menambah rasa hormat terhadap agama yang dikenalkan. Untuk mempertimbangkan rasa kekhawatiran tersebut, perguruan tinggi dinilai memiliki porsi yang tepat sebagai langkah kompromi dan realistis. Dengan status "maha" pada peserta didik, diharapkan kekhawatiran seperti yang telah dikemukakan di atas semestinya tidak terjadi lagi. Perguruan tinggi adalah kaum cendikiawan yang memiliki kedewasaan intelektual untuk memandang, menimbang dan menilai secara matang terhadap suatu peristiwa atau kejadian. Noor (2015) mengutarakan bahwa tidak relevan lagi apabila perguruan tinggi hanya mengajarkan pendidikan bagi agamanya sendiri. Sudah sekian lama pendidikan intra agama diperkenalkan mulai tingkat dasar hingga menengah atas. Oleh karena itu hendaknya 
perguruan tinggi mulai memperkenalkan tentang sejarah, ajaran dan spiritualitas berbagai agama di dunia. Sekali lagi bukan untuk dipercaya dan diterima. Pengetahuan tersebut dalam rangka memahami dan mengapresiasi. Kedewasaan seseorang dapat diperoleh jika telah melangkah jauh dan mengalami banyak kejadian. Pun dengan kedewasaan beragama bisa diperoleh jika seseorang telah mengenal dan mengapresiasi berbagai ajaran agama.

Pendidikan agama-agama juga mendorong mahasiswa untuk berpikir kritis. Mahasiswa dituntut melihat dunia dalam perpektif yang lebih luas bukan hanya berasal dari agama dan budayanya sendiri serta mempertimbangkan konsekuensi dan standar yang lebih luas pula. Pendidikan agama merupakan bagian dari pendidikan multikultur dan bukan dianggap sebagai angin lalu saja. Pendidikan agama-agama harus menjadi bagian dari kurikulum wajib di seluruh perguruan tinggi. Dengan begitu setiap mahasiswa mengenal beragam ajaran agama di dunia mulai dari Islam, Kristen/katolik, Hindu, Budha, Konguchu, dan mungkin agama-agama lokal. Selain pendidikan agama-agama, pendidikan etika adalah pelengkap pendidikan agama yang saling melengkapi. Bukankan agama telah mengajarkan moral baik dan moral buruk?. Sekilas, moral dan etika memiliki makna yang sama yakni acuan baik buruknya perbuatan. Dua kata tersebut sebenarnya dapat dibedakan.

Noor (2015:35), moral dalam agama diartikan sebagai motivasi dan inspirasi bagi penganutnya sebagai pedoman hidup. sedangkan etika merupakan argumentasi rasional yang memiliki dampak sosial, budaya dan politik. Etika lebih menekankan peran manusia dalam menjalani kehidupan yang beragam dan mengatasi permasalahan kehidupan secara etis. Noor menyebut kehidupan etis dalam modernitas saat ini memiliki tiga ciri. Pertama, kemajuan teknologi, komunikasi dan migrasi menyatukan umat manusia dengan latar belakang budaya, agama, warna kulit, bahasa tentunya berbeda. Nilai-nilai yang dibawa teknologi masuk pada pemikiran per individu yang patut menjadi perhatian etika. Kedua, permasalahan etika baru yang melampaui batas ajaran agama-agama secara umum seperti bayi tabung, pemanasan global, kapitalisme hak perempuan, kaum gay adalah contoh masalah etis yang memerlukan refleksi filosofis secara mendalam. Ketiga, muncul sikap kepedulian etis universal yang ditimbulkan dari permasalahan etika di berbagai belahan dunia seperti pernyataan, konvensi, ratifikasi dan deklarasi berikut dengan solusinya. Inilah yang mendorong etika harus mengglobal dan universal dan kita kenal sebagai etika global atau etika universal. Dengan demikian etika sebagai pelengkap pendidikan agama dipandang perlu karena sudut pandang agama berbeda dengan sudut pandang etis. Diakui pula bahwa agama bisa menjadi fondasi etika atas permasalahan yang terjadi.

\section{KESIMPULAN}

Pluralitas dalam beragama disikapi dengan kritis melalui pemikiran Dawan Rahardjo tentang civil society (masyarakat madani) yakni keberagaman agama merupakan refleksi nilai-nilai kebajikan umum dan intergrasi sosial. Civil society memiliki unsur nilai kabajikan umum dan integrasi sosial dijadikan dasar dalam berkehidupan untuk menghidari perpecahan antar umat beragama. Pemikiran Nur Colish Madjid juga selaras dengan Dawam bahwa pluralisme dibangun dengan tiga unsur yakni demokrasi, masyarakat madani (civil 
 \\ JSSH

society) dan etika (civility). Gagasan Madjid bahwa masyarakat madani adalah rumah demokrasi sedangkan etika merupakan kualitas dari masyarakat yang terbuka, toleran dan kebebasan yang bertanggungjawab. Hipotesa Hick tentang pluralitas bahwa ada satu relitas ketuhanan, tidak ada persepsi secara langsung terhadap tuhan, setiap agama memiliki jalan yang benar dan puncaknya bersifat transenden.

Pemikiran tersebut pada intinya merujuk pada perlunya pemahaman terhadap keberagaman tanpa adanya perpecahan karena setiap agama pada dasarnya memiliki tujuan kebenaran. Perpecahan yang memicu sikap intoleran dan radikalisme justru datang dari ketidakadilan ekonomi akibat modernisasi pembanguan bercorak pertumbuhan ekonomi. Modernitas inilah yang merusak nilai kearifan lokal agama-agama. Sebaliknya pembangunan dilakukan untuk meningkatkan indikator demokrasi: kontrol dari masyarakat pada setiap kebijakan publik dan kesetaraan tanpa membedakan suku, agama, ras, status sosial dan ekonomi. Oleh karena itu, pendidikan agama-agama dan etika pada perguruan tinggi dinilai penting karena pada lembaga ini potensi menciptakan pemikiran yang progresif bisa dikompromikan demi menciptakan gagasan dan konsep yang jernih yang mengutamakan persatuan dan keadilan umat manusia dari aspek politik, budaya dan ekonomi.

\section{DAFTAR PUSTAKA}

Anggraeni, Leni. 2012. Penerapan Metode Studi Kasus Dalam Upaya Meningkatkan Kemampuan Berpikir Kritis Mahasiswa Pada Mata Kuliah Hubungan Internasional. Jurnal Media Komunikasi FIS Vol. 11 .No 1
April $2012: 1$ - 15. Universitas Pendidikan Indonesia

Hasanah, Istikhomatul . 2016. Upaya Meningkatkan Sikap Peduli Sosial Dan Prestasi Belajar Pkn Materi Pengaruh Globalisasi Di Lingkungan Melalui Metode Studi Kasus Bikinan Siswa Pada Siswa Kelas IV SD Negeri 1 Karangbawang Kecamatan Ajibarang. Skripsi. PGSD UMP.

Nisaa, Milla Yuanti. 2015. Pengaruh Metode Pembelajaran Mind Map Terhadap Aktifitas Belajar IPS Siswa Kelas VII Semester 1 SMP Negeri 2 Batang Tahun Ajaran 2014/2015. Skripsi. UNNES.

Nurmala, Desy Ayu. Lulup Endah Tripalupi. Naswan Suharsono. 2014. Pengaruh Motivasi Belajar Dan Aktivitas Belajar Terhadap Hasil Belajar Akuntansi. Jurnal Jurusan Pendidikan Ekonomi. Undiksha.

Suyantiningsih dkk. 2011. Pengembangan Karakter Mahasiswa Melalui Model Pembelajaran Kolaboratif (Collaborative Learning) Pada Mata Kuliah Pameran Teknologi Pendidikan. Laporan Lesson Studi. UNY.

Wianti Anggit. 2015. Pengaruh Aktivitas Belajar Siswa Terhadap Hasil Belajar Geografi Pada Sekolah Menengah Atas di Kecamatan Gombong Kabupaten Kebumen. Skripsi. UNNES. 